\title{
Thermodynamics simulation performance of rice husk combustion with a realistic decomposition approach on the devolatilization stage
}

\section{Soen Steven}

Institut Teknologi Bandung

\section{Pandit Hernowo}

Institut Teknologi Bandung

Elvi Restiawaty

Institut Teknologi Bandung

Anton Irawan

Universitas Sultan Ageng Tirtayasa

Carolus Borromeus Rasrendra

Institut Teknologi Bandung

Yazid Bindar ( $\sim$ ybybyb@fti.itb.ac.id)

Institut Teknologi Bandung

\section{Research Article}

Keywords: Biomass, Degree of freedom, Flue gas, Adiabatic flame temperature, Air to fuel ratio

Posted Date: April 14th, 2021

DOl: https://doi.org/10.21203/rs.3.rs-359990/v1

License: (9) (i) This work is licensed under a Creative Commons Attribution 4.0 International License. Read Full License

Version of Record: A version of this preprint was published at Waste and Biomass Valorization on January 13th, 2022. See the published version at https://doi.org/10.1007/s12649-021-01657-x. 


\title{
Thermodynamics simulation performance of rice husk combustion with a realistic decomposition
} approach on the devolatilization stage

Soen Steven ${ }^{1}$, Pandit Hernowo ${ }^{1}$, Elvi Restiawaty ${ }^{1,2}$, Anton $\operatorname{Irawan}^{5}$, Carolus Borromeus Rasrendra ${ }^{1,3}$, and Yazid Bindar $^{1,4^{*}}$

\author{
${ }^{1}$ Department of Chemical Engineering
}

${ }^{2}$ Research Group on Design and Development of Chemical Engineering Processes

${ }^{3}$ Center for Catalysis and Reaction and Engineering

${ }^{4}$ Research Group on Biomass and Food Processing Technology

Faculty of Industrial Technology, Institut Teknologi Bandung, Jl. Ganesha 10, Bandung 40132, Indonesia

${ }^{5}$ Chemical Engineering Department, Faculty of Engineering, Universitas Sultan Ageng Tirtayasa, Jl. Jendral

Soedirman km 3 Cilegon, Banten, 42135, Indonesia

* Corresponding author: ybybyb@fti.itb.ac.id

\begin{abstract}
Rice husk has a great potential in its calorific value and silica content in ash which makes its valorization through combustion becomes important and interesting. This study presents the thermodynamics simulation performance of rice husk combustion using a realistic decomposition approach. A non-ideal gas approach and fugacity coefficient were also considered in the calculation. From this study, rice husk is devolatilized to form gases (63.37\%), tar $(8.69 \%)$, char $(27.94 \%)$, and all of these are then oxidized to form flue gas. The realistic decomposition approach calculated that about $2.6 \mathrm{MJ} / \mathrm{kg}$ of specific combustion energy is produced, the maximum combustion temperature is up to $1457^{\circ} \mathrm{C}$ for perfect insulation condition, and up to $1400^{\circ} \mathrm{C}$ if there is a heat loss. It is found that combustion equipped with larger excess air could quench the heat produced and reduce the combustion efficiency but could maintain the temperature at $700^{\circ} \mathrm{C}$. Furthermore, the thermodynamics simulation expressed that $\mathrm{NO}$ emission amount from rice husk combustion is negligible and there is still a probability for $\mathrm{CO}$ and $\mathrm{H}_{2}$ to be produced at above $500^{\circ} \mathrm{C}$ due to Boudouard reaction and homogeneous water gas shift reaction (WGSR). The study showed that a realistic decomposition approach could predict the rice husk combustion performance with a reasonable and logical result. Supplying excess air of about $180-200 \%$ is advantageous to keep the combustion temperature at $700^{\circ} \mathrm{C}$ in order to prevent silica crystalline formation which harms human
\end{abstract}


health, as well as suppressing NO emission and reducing $\mathrm{CO}$ emission from the simultaneous Boudouard and WGSR.

Keywords: Biomass, Degree of freedom, Flue gas, Adiabatic flame temperature, Air to fuel ratio

\section{Statement of Novelty}

So far, many established simulations have proposed a simple approach to the devolatilization stage. This is unrealistic because assumes that biomass will decompose to $\mathrm{C}, \mathrm{H}, \mathrm{O}, \mathrm{N}$ elements before entering oxidation. In the realistic decomposition approach, biomass is devolatilized not to form $\mathrm{C}, \mathrm{H}, \mathrm{O}, \mathrm{N}$ elements but light gases, liquid as tar, and solid as char. Interestingly, there is still a lack of study on it and therefore, This study discussed the rice husk combustion simulation performance with a realistic decomposition approach on the devolatilization stage. The results perform that this approach gives a reasonable agreement with the other researchers' results in terms of specific combustion energy, maximal combustion temperature, and flue gas composition analysis.

\section{Introduction}

Recently, biomass utilization as an alternative fossil fuel and chemicals surrogates has become a major concern. Rice husk is one of the abundant biomass in Indonesia which occupies approximately $20 \%$-wt from paddy, consists of nearly $20 \%$-wt rice husk ash, contains silica as much as $87 \%$-wt from its ash, and has a calorific value of 14-17 MJ/kg [1-3]. The high calorific value, as well as rich silica in ash, make rice husk important and interesting to be valorized. There are several stages occurred in the rice husk combustion, that is drying, devolatilization, oxidation, and ash formation $[1,4,5]$. So far, energy production through rice husk combustion mostly relied on direct experiments and then validate the results with thermodynamics simulation. They have focused on specific combustion energy calculation, rice husk combustion temperature monitoring, and flue gas composition prediction and analysis.

A study on combined heat power fuelled by rice husk with a maximal temperature of about $1100^{\circ} \mathrm{C}$ gave a specific rice husk consumption of $1.2-1.7 \mathrm{~kg} / \mathrm{kWh}[6]$ or recalculated as specific energy produced in the range of 2.123.00 MJ/kg. Apart from that, the case study from Pakistan stated that as much as $4947.28 \mathrm{MWh}$ of energy could be generated from 6432 tonnes of rice husk combustion [7] or equal to specific combustion energy of about 2.77 $\mathrm{MJ} / \mathrm{kg}$. The energy balance evaluation on $2.8 \mathrm{~g} / \mathrm{s}$ rice husk combustion for steam and hot air generation resulted 
in $21.09 \mathrm{~kJ} / \mathrm{s}$ of utilized energy [8] and it is equal to $7.53 \mathrm{MJ} / \mathrm{kg}$ of specific energy. Meanwhile, the rice husk combustion modelling study in a grate bed furnace had a maximum combustion temperature of $1406.85^{\circ} \mathrm{C}$ and flue gas exhaust temperature of $693.85^{\circ} \mathrm{C}$ with the composition of $\mathrm{N}_{2}, \mathrm{CO}, \mathrm{CO}_{2}, \mathrm{H}_{2} \mathrm{O}$, and remaining $\mathrm{O}_{2}$ [9].

The thermodynamics study from the research papers and well-established textbooks mostly proposed that at the devolatilization stage, biomass will decompose to $\mathrm{C}, \mathrm{H}, \mathrm{O}, \mathrm{N}$ elements prior to being oxidized to form flue gas [10-12]. This approach is simple but quite unrealistic so that it should be developed with a more realistic one. Realistic decomposition assumes that rice husk devolatilization products are not $\mathrm{C}, \mathrm{H}, \mathrm{O}, \mathrm{N}$ elements but gases, tar, and char [10]. Nevertheless, there is still a lack of study on it and therefore, this study intends to discuss the thermodynamics simulation performance of rice husk combustion with a realistic decomposition approach. The discussion comprises of problem preliminary analysis, devolatilized products result, specific energy produced from rice husk combustion, adiabatic flame temperature, air supply strategy for maintaining rice husk combustion temperature, and the flue gas composition analysis due to the attendance of Boudouard reaction and homogeneous water gas shift reaction (WGSR).

\section{Methods}

\subsection{Devolatilized products prediction calculation}

In this study, rice husk has a calorific value of $14.95 \mathrm{MJ} / \mathrm{kg}$. The ultimate and proximate analysis results are given in Table 1 . The proximate analysis procedure is performed at $900^{\circ} \mathrm{C}$ follows ASTM $3175-07$ procedure, whereas the combustion occurred at $T=700^{\circ} \mathrm{C}$.

Table 1. Ultimate and proximate analyses of rice husk

\begin{tabular}{cccc}
\hline \multicolumn{2}{c}{ Ultimate Analysis (Dry Basis) } & \multicolumn{2}{c}{ Proximate Analysis (As-received) } \\
\hline $\mathrm{C}$ & $37.95 \%$ & Moisture & $8.98 \%$ \\
$\mathrm{H}$ & $5.41 \%$ & Volatile Matter & $58.13 \%$ \\
$\mathrm{O}$ & $36.56 \%$ & Fixed Carbon & $15.49 \%$ \\
$\mathrm{~N}$ & $0.96 \%$ & Ash & $17.40 \%$ \\
\hline
\end{tabular}

A volatile enhancement factor $V_{E}$, which is commonly found in $0.8-1.3$, plays a role to correct the devolatilized product at a temperature beyond $900^{\circ} \mathrm{C}[10,11]$. To determine $V_{E}$, the biomass type number $\left(N_{C T}\right)$ should be calculated first as in equation 1a. The $N_{C T}$ value is then applied to determine the predicted volatile matter value $\left(Y_{V M}^{\prime}\right)$, equation $1 \mathrm{~b}$. Subsequently, equation $1 \mathrm{c}$ is a temperature correction function, $f_{5}(T)$ in ${ }^{\circ} \mathrm{C}$ unit, which is later employed in equation 1d to obtain the predicted devolatilized products mass fraction $\left(Y_{V Y}^{\prime}\right)$. Afterward, $V_{E}$ is calculated following equation 1e $[10,11]$. Rice husk devolatilization produces gases, tar, and char. Gases were 
represented with $\mathrm{CO}, \mathrm{H}_{2}, \mathrm{CO}_{2}, \mathrm{CH}_{4}, \mathrm{HCN}$, and $\mathrm{H}_{2} \mathrm{O}$. Tar was assumed to consist of $\mathrm{C}_{16} \mathrm{H}_{18}, \mathrm{C}_{10} \mathrm{H}_{14} \mathrm{O}_{2}, \mathrm{C}_{7} \mathrm{H}_{8} \mathrm{O}$, and $\mathrm{C}_{9} \mathrm{H}_{7} \mathrm{~N}$. Char was presumed to contain only C. Each product amount is determined from equation 2 and should consistent with the value from dry-ash-free basis of proximate and ultimate analysis [10, 11].

$$
\begin{aligned}
& N_{C T}=\frac{Y_{C, u l t}^{2}}{Y_{H, u l t} \cdot Y_{O, u l t}} \\
& Y_{V M}^{\prime}=\exp \left[0.031-0.029 \ln N_{C T}-0.038\left(\ln N_{C T}\right)^{2}\right] \\
& f_{5}(T)=3.87\left(\frac{T}{900}\right)^{5}-28.28\left(\frac{T}{900}\right)^{4}+80.87\left(\frac{T}{900}\right)^{3}-112.8\left(\frac{T}{900}\right)^{2}+77.07\left(\frac{T}{900}\right)-20.26 \\
& Y_{V Y}^{\prime}=Y_{V M}^{\prime} \cdot \exp \left[f_{5}(T)\right] \\
& Y_{E}=\frac{Y_{V Y}^{\prime}}{Y_{V M}^{\prime}}=\frac{Y_{V Y}}{Y_{V M}} \\
& Y_{c h a r}=1-Y_{V Y}=1-\sum Y_{i} \\
& Y_{C, u l t}=Y_{c h a r}+\sum\left(\frac{Y_{C, i} \cdot A r_{C}}{M r_{i}}\right) \\
& Y_{H, u l t}=\sum\left(\frac{Y_{H, i} \cdot A r_{H}}{M r_{i}}\right) \\
& Y_{O, u l t}=\sum\left(\frac{Y_{O, i} \cdot A r_{O}}{M r_{i}}\right) \\
& Y_{N, u l t}=\sum\left(\frac{Y_{N, i} \cdot A r_{N}}{M r_{i}}\right)
\end{aligned}
$$

where $Y_{V Y}$ is the actual devolatilized products mass fraction, $Y_{V M}$ is the volatile matter value from proximate analysis on dry-ash-free basis, $Y_{i}$ is the $\mathrm{i}^{\text {th }}$ component of actual devolatilized products mass fraction, $Y_{\text {char }}$ is the char fraction, $Y_{C, i}$ is the number of $\mathrm{C}$ atoms in $\mathrm{i}^{\text {th }}$ component, $Y_{H, i}$ is the number of $\mathrm{H}$ atoms in $\mathrm{i}^{\text {th }}$ component, $Y_{O, i}$ is the number of $\mathrm{O}$ atoms in $\mathrm{i}^{\text {th }}$ component, $Y_{N, i}$ is the number of $\mathrm{N}$ atoms in $\mathrm{i}^{\text {th }}$ component, $Y_{u l t}$ is the $\mathrm{C}-\mathrm{H}-\mathrm{O}-\mathrm{N}$ content ultimate analysis in dry-ash-free basis, $A r$ is the atomic weight for C-H-O-N, and $M r_{i}$ is the molecular weight of $\mathrm{i}^{\text {th }}$ component.

In the rice husk combustor, all devolatilized products react with oxygen from the air. The air amount was varied under stoichiometric and excess conditions. The flue gas temperature was also varied from $200-700^{\circ} \mathrm{C}$. The excess air $(E A)$ is calculated from equation 3 and the $\mathrm{O}_{2}$ and $\mathrm{CO}_{2}$ percentages in the flue gas are acquired from equation 4 , respectively.

$$
\begin{aligned}
& E A=\frac{n_{a}-n_{s}}{n_{s}} \times 100 \% \\
& O_{2} \text { in flue gas }=\frac{n_{O_{2}, a}-n_{O_{2}, s}}{n_{f g}} \times 100 \% \\
& C O_{2} \text { in flue gas }=\frac{n_{C O_{2}}}{n_{f g}} \times 100 \%
\end{aligned}
$$


where $n_{a}$ is the actual air amount; $n_{s}$ is the stoichiometric air amount; $n_{O_{2}, a}$ is the actual oxygen amount; $n_{O_{2}, s}$ is the stoichiometric oxygen amount; and $n_{\mathrm{CO} 2}$ is the carbon dioxide amount; and $n_{f g}$ is the flue gas amount.

\subsection{Combustion efficiency calculation}

Combustion efficiency requires inlet and outlet enthalpy calculation with the reference temperature of $25^{\circ} \mathrm{C}$. Inlet enthalpy $\left(H_{i n}\right)$ was derived from biomass and air inlet enthalpy. Air inlet enthalpy considered residual enthalpy $\left(H^{R}\right)$ from Pitzer-Lee-Kesler Generalized Correlation which involves acentric factor $(\omega)$ and critical temperature $\left(T_{c}\right)$ properties [13]. The outlet enthalpy $\left(H_{\text {out }}\right)$ considered ash and flue gas sensible heat as well as $5 \%$ heat loss $\left(H_{\text {loss }}\right)$ from inlet enthapy due to radiation. The heat capacity $(\mathrm{Cp})$ for all components was a temperaturedependent polynomial function. All properties constant are adapted from common databanks [13-15]. Combustion efficiency $\left(\eta_{c}\right)$ is derived from the difference between inlet and outlet enthalpy including heat loss, equation $5[3]$.

$\eta_{c}=\left(1-\frac{H_{\text {out }}+H_{\text {loss }}}{H_{\text {in }}}\right) \times 100 \%$

\subsection{Thermodynamics calculation procedure}

Thermodynamics calculation entangled fugacity coefficient $(\phi)$ and was determined using a generic cubic equation of state, as served in equation 6. It also involved the compressibility factor $(Z)$ which requires critical pressure $\left(P_{c}\right)$ and was determined using Redlich-Kwong, Soave-Redlich-Kwong, and Peng-Robinson models. The coefficient of $\beta, q, I, \Omega, \Psi, \alpha, \sigma$, and $\varepsilon$ for the calculation are taken from state parameters assignment $[13,16]$.

$\phi=\exp (Z-1-\ln (Z-\beta)-q I)$

The interaction between flue gas with remaining biomass through Boudouard reaction and homogeneous water gas shift reaction (WGSR) were assumed ideal and the calculation was carried out using the Gibbs Energy minimization as seen in equation 7 which considers the temperature-dependent of equilibrium constant $(K)$ and the stoichiometric coefficient of each component $\left(v_{i}\right)$ [13]. The iterative calculation should be addressed until the error tolerance is below $10^{-6}$.

$\prod_{i=1}^{n}\left(y_{i} \phi_{i}\right)^{v_{i}}=K$

\section{Result and discussion}

3.1.Problem preliminary analysis: Degree of freedom 
In this study, rice husk combustion occurred at 1 bar and feed inlet at $25^{\circ} \mathrm{C}$. The combustion is assumed to be complete until remains rice husk ash. The flue gas produced from the combustion, hence, is composed of $\mathrm{CO}_{2}$, $\mathrm{H}_{2} \mathrm{O}, \mathrm{NO}, \mathrm{N}_{2}$, and the remaining $\mathrm{O}_{2}$ [9]. $\mathrm{NO}$ compound, as one of the $\mathrm{NO}_{\mathrm{X}}$ constituents, is chosen due to the process condition tends to form $\mathrm{NO}$ than $\mathrm{NO}_{2}$ or $\mathrm{N}_{2} \mathrm{O}$ [17]. A preliminary analysis in the form of degree of freedom analysis (DoF) is conducted to determine the problem completion criteria. Figure 1 served the rice husk combustion block diagram embedded with DoF analysis result. It can be seen that DoF value is equal to 0 for both mass balance and mass-energy balance, which implies the problems are well-specified and able to be solved either separately (decoupled) or simultaneously (coupled) [12].

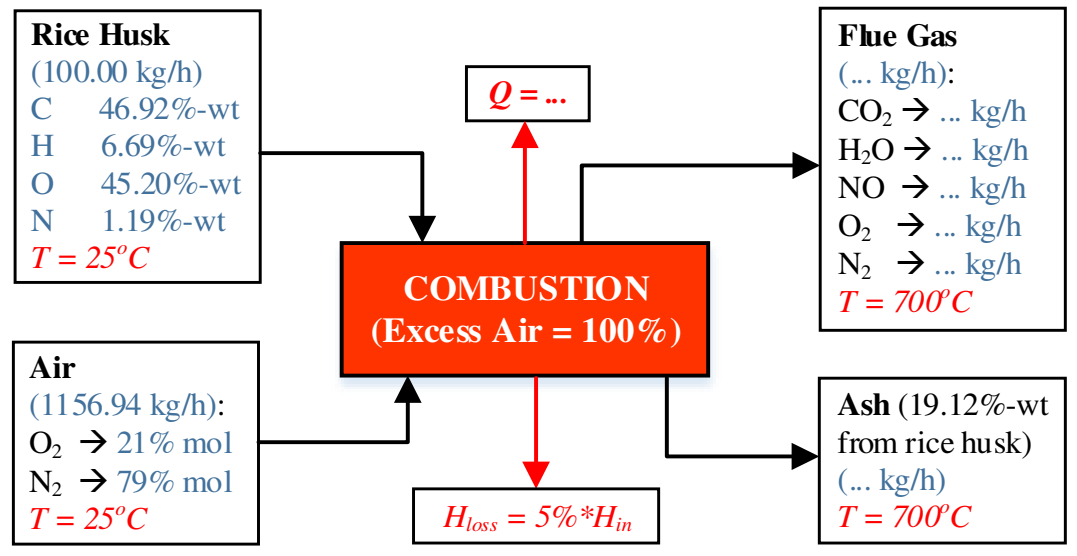

\begin{tabular}{|c|c|c|}
\hline \multicolumn{3}{|c|}{ Degree of freedom analysis } \\
\hline & Mass balance & Mass-energy balance \\
\hline Mass stream variables & (12) & $(12)$ \\
\hline Energy stream variables & $(0)$ & (6) \\
\hline Linearly independent element balances & $(-5)$ & $(-5)$ \\
\hline Energy equation & $(0)$ & $(-1)$ \\
\hline Known compositions & $(-4)$ & $(-4)$ \\
\hline Known energy variables & $(0)$ & $(-5)$ \\
\hline Basis & $(-1)$ & $(-1)$ \\
\hline Known flowrates & $(-1)$ & $(-1)$ \\
\hline Supplementary equations & $(-1)$ & $(-1)$ \\
\hline Degree of freedom & 0 & 0 \\
\hline
\end{tabular}

Figure 1. Rice husk combustion block diagram with DoF analysis

\subsection{Rice husk combustion calculation result using realistic decomposition}

The calculation for air inlet condition should utilize the real (non-ideal) gas approach and for the flue gas exit condition fulfills the ideal gas approach. Flue gas pressure and temperature conditions neglect the intermolecular interactions due to the high kinetic energy, which reflects the ideal gas characteristics [18]. When the temperature becomes lower resembles the inlet condition, kinetic energy becomes low and allows for significant intermolecular interactions $[14,16,18]$. Consequently, a real gas approach for inlet state should be considered. According to the realistic decomposition approach calculation, the $V_{E}$ value of 0.91 will lead to the actual devolatilized products as schemed in Figure 2. 


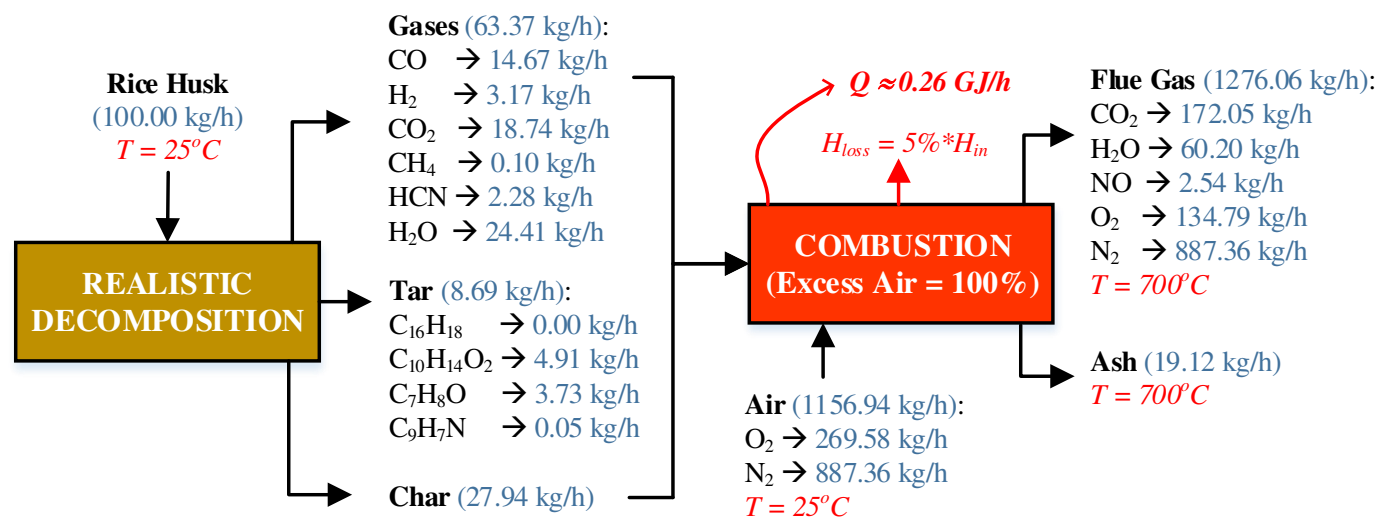

Figure 2. Rice husk combustion calculation based on realistic decomposition

The realistic decomposition leads to the production of $63.37 \%$ gases, $8.69 \%$ tar, and $27.94 \%$ char. The gases are dominated by $\mathrm{H}_{2} \mathrm{O}, \mathrm{CO}_{2}$, and $\mathrm{CO}$ while the major component of tar is $\mathrm{C}_{10} \mathrm{H}_{14} \mathrm{O}_{2}$. Water is not produced from moisture but molecule decomposition, known as chemical water. These gases, tar, and char are then oxidized by $100 \%$ excess air $(1156.94 \mathrm{~kg} / \mathrm{h})$ to produce $1276.06 \mathrm{~kg} / \mathrm{h}$ of flue gas with the composition of $13.69 \% \mathrm{CO}_{2}, 4.79 \%$ $\mathrm{H}_{2} \mathrm{O}, 0.20 \% \mathrm{NO}, 70.60 \% \mathrm{~N}_{2}$, and $10.72 \%$ remaining $\mathrm{O}_{2}$. The specific energy of about $2.6 \mathrm{MJ} / \mathrm{kg}$ rice husk is released at flue gas temperature of $700^{\circ} \mathrm{C}$ with $5 \%$ heat loss. The value of this specific energy is still is in the range as stated by Chang et al. [6] and also quite similar to the research conducted by Memon et al. [7], but still far lower than Kwofie et al. [8]. This implies that a realistic decomposition approach for rice husk combustion calculation has a reasonable and logical performance.

The excess air in the combustion process could be represented by the $\mathrm{O}_{2}$ or $\mathrm{CO}_{2}$ concentration in the flue gas [8]. Usually, the combustor is equipped with $\mathrm{O}_{2}$ or $\mathrm{CO}_{2}$ detector which is installed at the outlet pipe to record the concentration in the flue gas. In absence of gas detector, the flue gas could also be analyzed through gas chromatography to ensure the $\mathrm{O}_{2}$ and $\mathrm{CO}_{2}$ amount [19]. This calculation is also able to deliver a nomogram (Figure 3) to interpret the relation between $\mathrm{O}_{2}$ or $\mathrm{CO}_{2}$ concentration in the flue gas and excess air in the combustion process. Combustion efficiency represents the effective heat utilized in the combustion process where the value becomes lower at a higher excess air and flue gas temperature [20]. The efficiency alleviation due to the higher flue gas temperature is somewhat significant compare to the larger excess air supplied. The nomogram describes that about $10 \%$ of $\mathrm{O}_{2}$ or $9 \%$ of $\mathrm{CO}_{2}$ in the flue gas reflected the $50 \%$ of excess air involved in the combustion. In this condition, the combustion efficiency is about $77 \%$ at flue gas outlet temperature of $200^{\circ} \mathrm{C}$ and declining to $21 \%$ at outlet temperature of $700^{\circ} \mathrm{C}$. When flue gas contains higher oxygen content, let's say $18 \%$ of $\mathrm{O}_{2}$ or $8.2 \%$ 
of $\mathrm{CO}_{2}$, it means that the combustion takes place using $100 \%$ of excess air. The combustion efficiency is slightly reduced to $74 \%$ and $15 \%$ at a flue gas outlet temperature of $200^{\circ} \mathrm{C}$ and $700^{\circ} \mathrm{C}$, in a successive term.

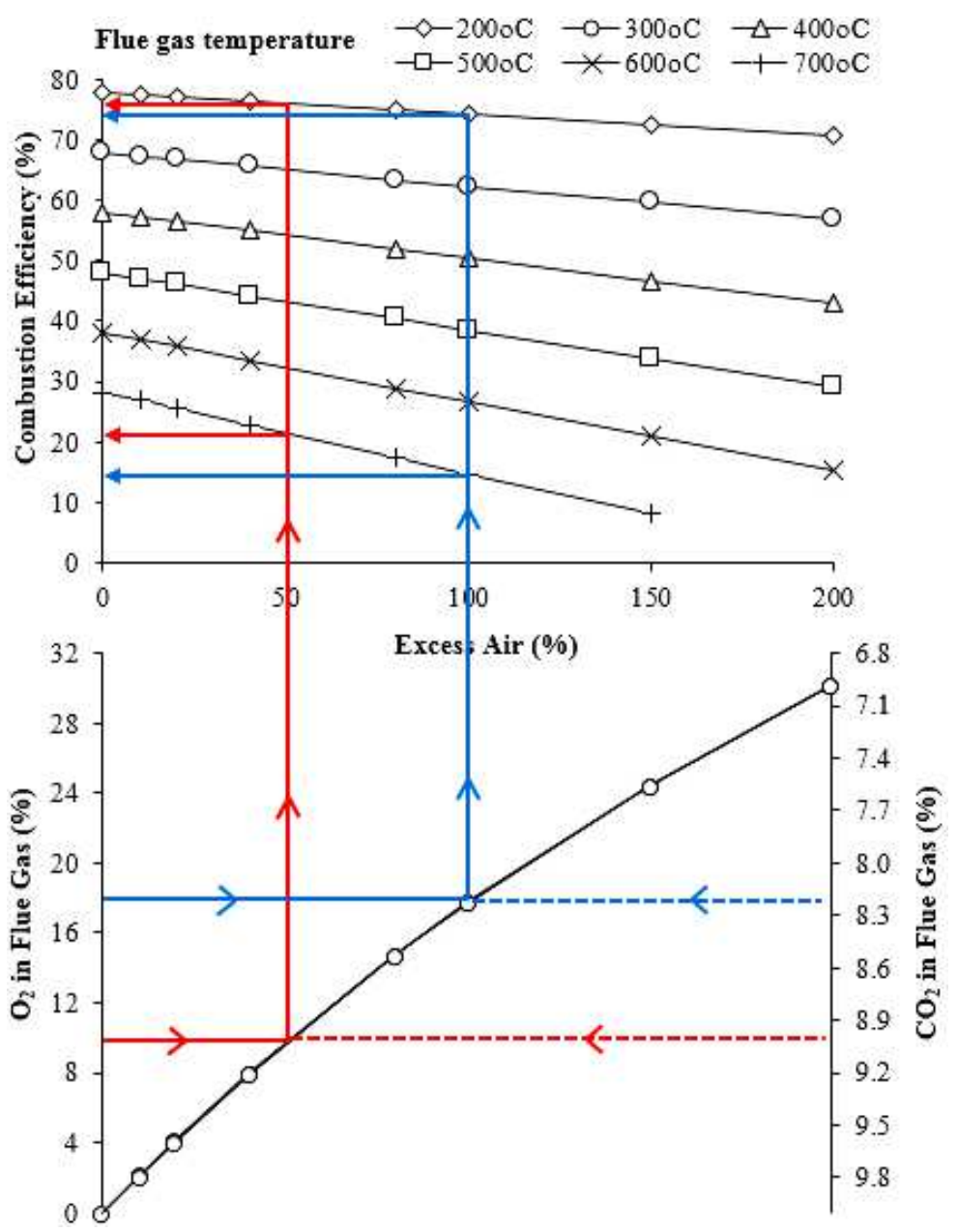

Figure 3. Rice husk combustion efficiency nomogram

At higher excess air, substantial nitrogen as an inert gas creates a quenching effect where it absorbs the heat produced and carries it out from the combustor [21, 22]. This impacts on reducing combustion effective heat and lead to low combustion efficiency. Besides that, the higher flue gas temperature at a constant excess air will also lead to poorer combustion efficiency. High flue gas temperature indicates the heat has already flown out from the combustor before it is used for combustion purposes. Accordingly, it is important to utilize the flue gas sensible heat through cogeneration and combine cycle could increase the efficiency $[6,23,24]$ although there is a minimum allowable flue gas temperature usually $200^{\circ} \mathrm{C}$ to prevent flue gas condensation.

\subsection{Adiabatic flame temperature (AFT) and air supply strategy for rice husk combustion}

Adiabatic flame temperature is the highest theoretical temperature achieved at perfect insulation of the combustion process which is unique for each fuel and only depends on calorific value as long as in absence of molecules 
dissociation [25]. AFT is determined through trial error with the assumption of two conditions: perfect insulation condition with no heat loss and 5\% heat loss due to radiation. The maximum temperature of this rice husk combustion is calculated up to $1457^{\circ} \mathrm{C}$ for perfect insulation and this result is slightly lower with the value acquire from Anshar et al. [9]. Again, the realistic decomposition shows its ability to predict the maximal rice husk combustion temperature with a rational result. The negligible discrepancy from another result is strongly caused by different rice husk chemical properties. Subsequently, the heat loss due to radiation will give a quite lower AFT with a discrepancy around $30-60^{\circ} \mathrm{C}$ as notified in Figure 4.

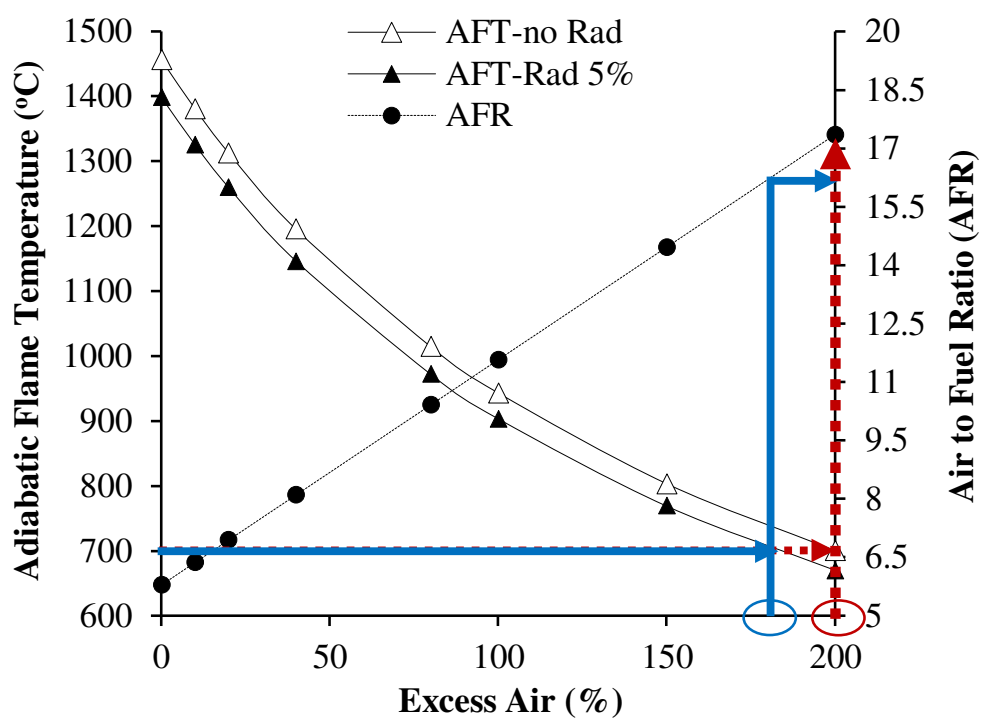

Figure 4. AFT for rice husk combustion at various excess air

Similar to the previous explanation, larger excess air provides lower AFT. The nitrogen in excess air dilutes and cooled down the flue gas temperature due to the sensible heat absorption [21, 22]. Rice husk combustion is usually maintained at $700^{\circ} \mathrm{C}$ in order to prevent silica crystalline formation on its ash which could threaten human respiratory systems [26]. To achieve this, the excess air of $200 \%$ or air to fuel ratio (AFR) of 17.35 should be supplied for rice husk combustion under perfect insulation of combustor. If there is a $5 \%$ heat loss due to radiation, the excess air supply of about $180 \%$ or AFR 16.19 is still allowable.

\subsection{Flue gas composition analysis}

The biomass thermal process through combustion is a complex set of reactions that produces $\mathrm{CO}, \mathrm{H}_{2}, \mathrm{CO}_{2}, \mathrm{H}_{2} \mathrm{O}$, $\mathrm{NO}, \mathrm{N}_{2}$, and remaining $\mathrm{O}_{2}[1,5]$. The calculated fugacity coefficient of these gases is 1 for ideal gas and between 0-1 for real gas, which means that there is an intermolecular force attraction [18]. Nevertheless, there is a condition that the fugacity coefficient value is more than 1 which informs that there is an intermolecular force repulsion $[16$, 
18]. The fugacity coefficient for all flue gases is depicted in Figure 5. Calculation with Redlich-Kwong, SoaveRedlich-Kwong, and Peng-Robinson models show slightly similar results. It is also shown that all flue gases have an average fugacity coefficient of nearly 1 . The gas acts more ideal at a higher temperature, which is characterized by a fugacity coefficient that is closer to $1[13,16]$. The fugacity coefficient value is then used for Gibbs Energy minimization calculation to predict the flue gas composition.

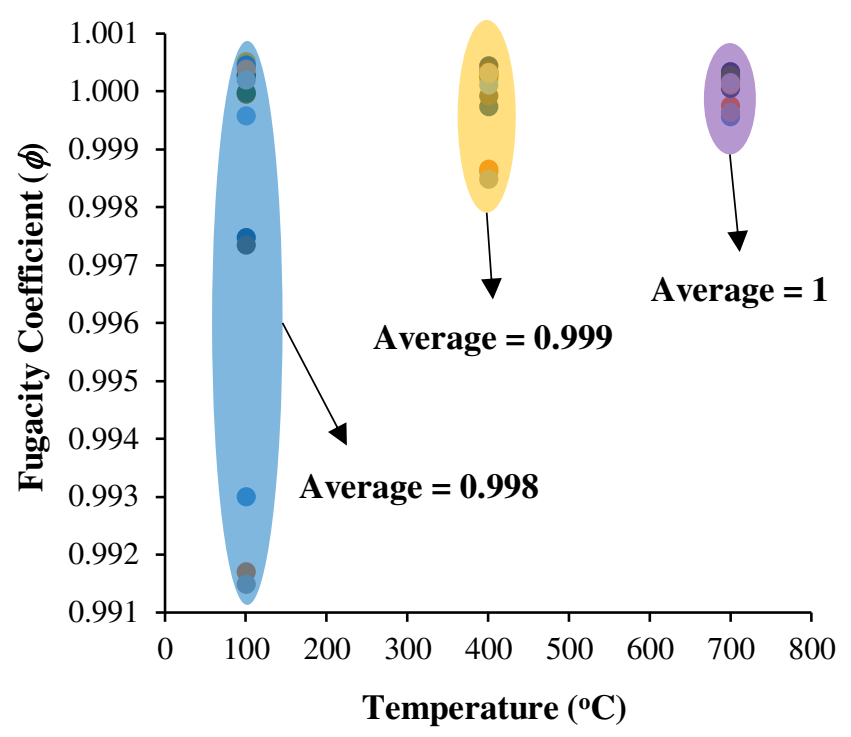

Figure 5. Flue gas fugacity coefficient at various temperature

At a temperature of up to $700^{\circ} \mathrm{C}$, the complete oxidation of compounds based on $\mathrm{C}$ and $\mathrm{H}$ atoms are still spontaneous whereas an opposite pattern is found for $\mathrm{N}$ atom $[2,13]$. In the previous section, NO calculation resulted in $0.20 \%$ or $25.4 \mathrm{~g}$ NO emission for $1 \mathrm{~kg}$ of combusted rice husk (see Figure 2). Meanwhile, thermodynamics calculation reveals that $\mathrm{NO}$ (on behalf of the major $\mathrm{NO}_{\mathrm{X}}$ compound) has a very low equilibrium constant, $3.88 * 10^{-4}$ at $700^{\circ} \mathrm{C}$. Moreover, biomass combustion is frequently found at below $1000^{\circ} \mathrm{C}$ due to the more inferior calorific value than fossil fuel, which leads to the negligence of the NO emission value $[2,17,27]$.

On the other hand, $\mathrm{CO}_{2}$ and $\mathrm{H}_{2} \mathrm{O}$ are spontaneously formed and the $\mathrm{CO}$ produced from the decomposition will also immediately convert to $\mathrm{CO}_{2}$. However, the $\mathrm{CO}$ complete oxidation is only undergone when air is supplied surpassing its stoichiometric value. Following Le-Chatelier principles, $\mathrm{CO}$ oxidation to $\mathrm{CO}_{2}$ is more favored when more oxygen is supplied [28, 29]. The advantage of providing excess air is clearly to suppress the CO emission. Even though there is still a probability for $\mathrm{CO}$ and $\mathrm{H}_{2}$ to be produced which is caused by the unburnt biomass and $\mathrm{CO}_{2}$ in the combustor allows Boudouard reaction to occur $[28,30]$. The $\mathrm{CO}$ produced has a chance to react with $\mathrm{H}_{2} \mathrm{O}$ to form $\mathrm{H}_{2}$ through homogeneous WGSR. 
In pursuance of the single reaction simulation, the Boudouard reaction is feasible when the temperature surpassing $500^{\circ} \mathrm{C}$. The equilibrium conversion of this reaction is found higher along with the increasing temperature, due to the endothermic reaction. The opposite pattern is found in homogeneous WGSR, which is exothermic and could undergo at a lower temperature [31]. However, the equilibrium conversion decreases at a larger temperature. For simultaneous reaction, WGSR occurs only when the temperature is above $500^{\circ} \mathrm{C}$ due to the $\mathrm{CO}$ compound is produced above this temperature. The equilibrium conversion for both single reactions is shown in Figure 6a and the conversion of the simultaneous reaction is plotted in Figure $6 \mathrm{~b}$.
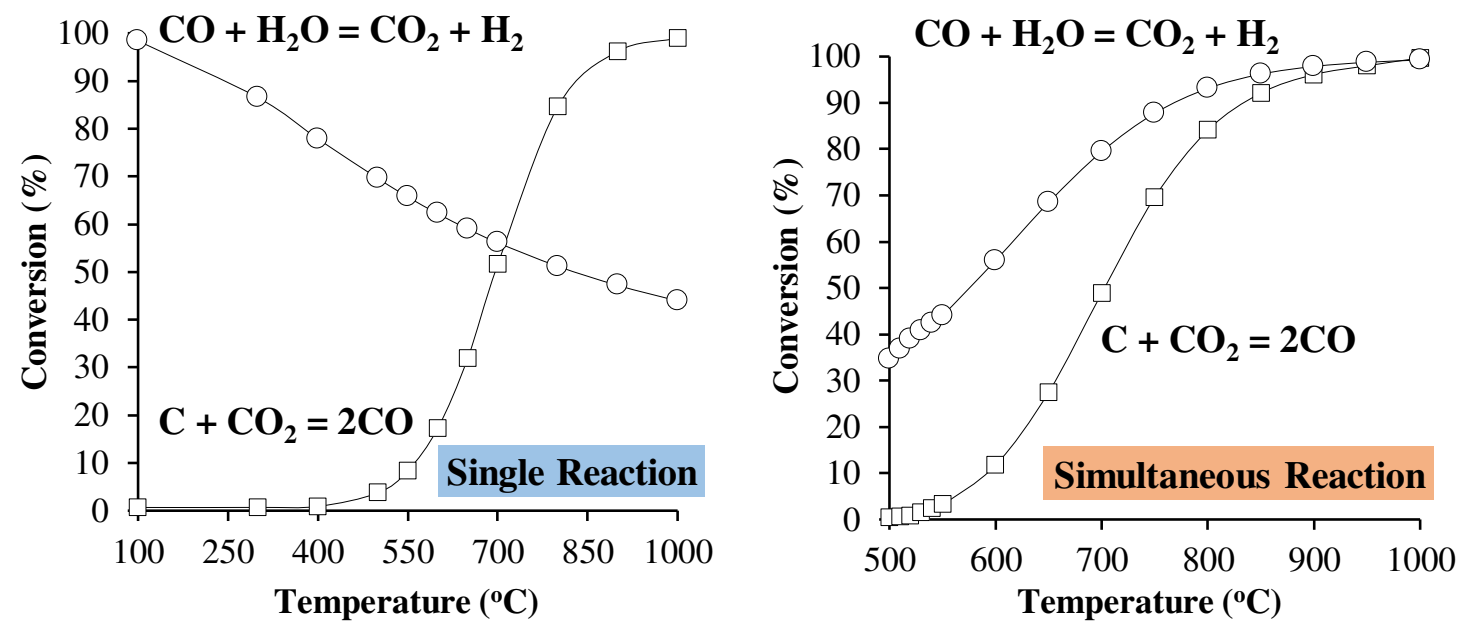

Figure 6. Equilibrium conversion for Boudouard and WGSR: single reaction (a) and simultaneous reaction (b)

The calculated flue gas composition from Figure 2 is then corrected due to the presence of simultaneous Boudouard-WGSR and the values at various temperatures can be seen in Figure 7. This figure informs that the $\mathrm{CO}$ production as well as $\mathrm{CO}_{2}$ consumption from simultaneous Boudouard-WGSR changes from 8.24-27.30\% and $19.23-13.71 \%$ as the temperature rises from $500-1000^{\circ} \mathrm{C}$. Besides that, $\mathrm{H}_{2}$ production is also intensified from $1.97-4.77 \%$ as well as $\mathrm{H}_{2} \mathrm{O}$ alleviation from $2.82-0.02 \%$ in line with the increasing temperature. A similar pattern is found in the thermodynamics simulation study conducted by Li et al. where $\mathrm{CO}$ and $\mathrm{H}_{2}$ are obtained in higher yield and at the same time $\mathrm{CO}_{2}$ yield is decreasing as a temperature increase from $700-850^{\circ} \mathrm{C}$ [32]. This figure also indicates that a high amount of $\mathrm{CO}$ could be produced from combustion through Boudouard reaction at above $500^{\circ} \mathrm{C}$. This gas is poisonous to humans, so the amount should be suppressed. Again, providing excess air could allow the $\mathrm{CO}$ spontaneous reaction with oxygen to form $\mathrm{CO}_{2}$. Thus, maintaining rice husk combustion temperature below $700^{\circ} \mathrm{C}$, apart from suppressing $\mathrm{CO}$ and NO production, also prevents the silica phase in ash into crystalline and silica melting $[2,4,26,33]$. 


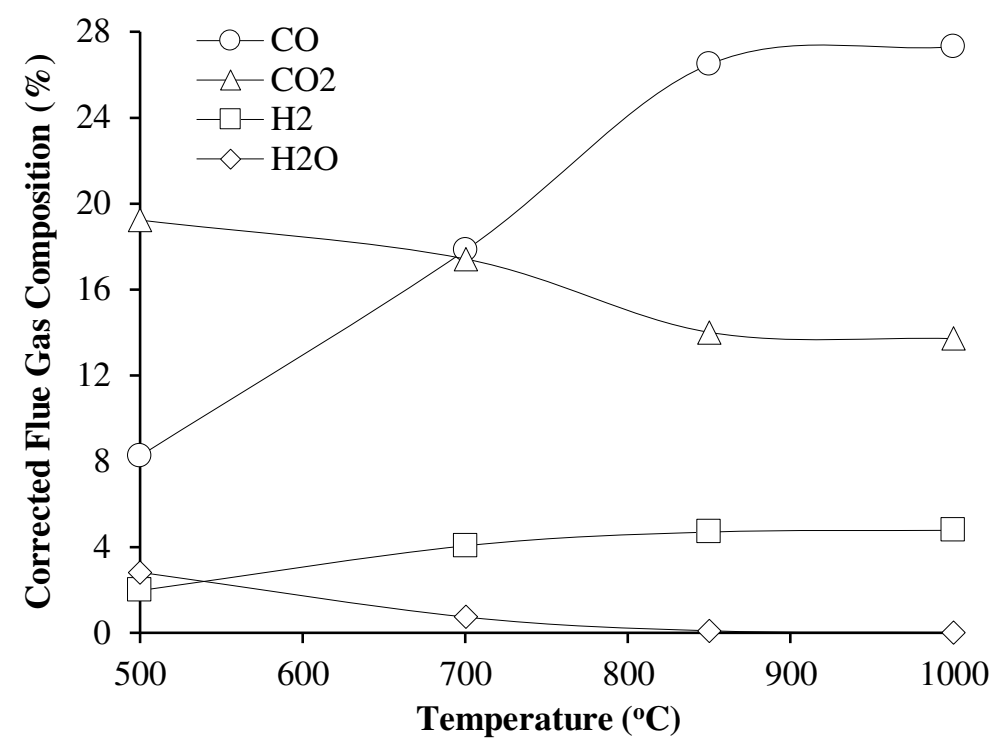

Figure 7. Corrected flue gas composition

\section{Conclusion and suggestion}

The thermodynamics simulation performance of rice husk combustion has been studied. Under a realistic decomposition approach, rice husk devolatization produce $63.37 \%$ gases, $8.69 \%$ tar, and $27.94 \%$ char which are then oxidized by $100 \%$ excess air to produce flue gas with the composition of $13.69 \% \mathrm{CO}_{2}, 4.79 \% \mathrm{H}_{2} \mathrm{O}, 0.20 \%$ $\mathrm{NO}, 70.60 \% \mathrm{~N}_{2}$, and $10.72 \%$ remaining $\mathrm{O}_{2}$. About $2.6 \mathrm{MJ} / \mathrm{kg}$ rice husk is also released at flue gas temperature of $700^{\circ} \mathrm{C}$ with $5 \%$ heat loss. From this study, rice husk with $14.95 \mathrm{MJ} / \mathrm{kg}$ of calorific value could achieve the highest theoretical combustion temperature around $1457^{\circ} \mathrm{C}$ for perfect insulation condition and under $5 \%$ heat loss due to radiation could reduce the combustion temperature by about $30-60^{\circ} \mathrm{C}$. According to the thermodynamics simulation, $\mathrm{NO}$ emission is extremely low as long as the combustion temperature still below $700^{\circ} \mathrm{C}$. Besides, $\mathrm{CO}$ emission is still possible to exist if the remaining biomass and $\mathrm{CO}_{2}$ react through simultaneous reactions of Boudouard-WGSR. Although biomass combustion temperature is definitely lower than fossil fuel combustion, maintaining rice husk combustion below $700^{\circ} \mathrm{C}$ is a necessity in order to suppress $\mathrm{CO}$ and $\mathrm{NO}$ emissions as well as preventing silica in ash phase change to crystalline which harms humans. Providing excess air of about 180$200 \%$ could be an alternative solution for the problems.

\section{Acknowledgment}

This study is the beginning part of the doctoral research in Chemical Engineering ITB. Mr. Steven wishing to acknowledge the tuition fee waiver provided by Voucher ITB no. 186/SK/I1.B01/KM/2019. The authors would also thank the Riset Unggulan PT grants for the research funding. 


\section{Declarations}

Conflict of interest There is no conflict or competing of interest to declare.

\section{References}

1. Demirbas, A.: Combustion characteristics of different biomass fuels. Prog. Energy Combust. Sci. 30, 219-230 (2004). https://doi.org/10.1016/j.pecs.2003.10.004

2. Werther, J., Saenger, M., Hartge, E.U., Ogada, T., Siagi, Z.: Combustion of agricultural residues. Prog. Energy Combust. Sci. 26, 1-27 (2000). https://doi.org/10.1016/S0360-1285(99)00005-2

3. Armesto, L., Bahillo, A., Veijonen, K., Cabanillas, A., Otero, J.: Combustion behaviour of rice husk in a bubbling fluidised bed. Biomass and Bioenergy. 23, 171-179 (2002). https://doi.org/10.1016/S09619534(02)00046-6

4. Vassilev, S. V., Baxter, D., Vassileva, C.G.: An overview of the behaviour of biomass during combustion: Part I. Phase-mineral transformations of organic and inorganic matter. Fuel. 112, 391-449 (2013). https://doi.org/10.1016/j.fuel.2013.05.043

5. Nunes, L.J.R., Matias, J.C.O., Catalão, J.P.S.: Mixed biomass pellets for thermal energy production: A review of combustion models. Appl. Energy. 127, 135-140 (2014). https://doi.org/10.1016/j.apenergy.2014.04.042

6. Chang, C.T., Costa, M., Villetta, M. La: Thermodynamic and economic analysis of a combined CHP system fuelled with rice husk. (2017)

7. Memon, T.A., Harijan, K., Soomro, M.I., Meghwar, S., Valasai, G.D., Khoharo, H.: Potential of electricity generation from rice husk: A case study of rice mill. Sindh Univ. Res. J. -Science Ser. 49, 495--498 (2017). https://doi.org/10.26692/surj/2017.09.05

8. Kwofie, E.M., Ngadi, M., Sotocinal, S.: Thermodynamic evaluation of a rice husk fired integrated steam and hot air generation unit for rice parboiling. Energy. 128, 39-49 (2017). https://doi.org/10.1016/j.energy.2017.04.013

9. Anshar, M., Ani, F.N., Kader, A.S.: Combustion characteristics modeling of rice husk as fuel for power plant in Indonesia. Appl. Mech. Mater. 695, 815-819 (2014). https://doi.org/10.4028/www.scientific.net/amm.695.815

10. Bindar, Y., Riza, A., Susanto, H., Sasongko, D.: Coal decomposition method based on element balance 
and devolatilization theory from proximate and ultimate analysis data. J. Tek. Kim. Indones. 6, 549-562 (2007)

11. Bindar, Y.: New correlations for coal and biomass pyrolysis performances with coal-biomass type number and temperature. J. Eng. Technol. Sci. 45, 275-293 (2013)

12. Reklaitis, G. V.: Introduction to Material and Energy Balances. (1983)

13. Smith, J.M., Van Ness, H.C., Abbott, M.M.: Introduction to Chemical Engineering Thermodynamics. (2005)

14. Poling, B.E., Prausnitz, J.M., O’Connell, J.P.: The Properties of Gases and Liquids, Fifth Edition. (2001)

15. Poling, B.E., Thomson, G.H., Friend, D.G., Rowley, R.L., Wilding, W.V.: Physical and Chemical Data. In: Perry’s Chemical Engineers’ Handbook, Eighth Edition. pp. 2-517 (2008)

16. Prausnitz, J.M., Lichtenthaler, R.N., de Azevedo, E.G.: Molecular Thermodynamics of Fluid-Phase Equilibria, Third Edition. (1999)

17. Steven, S., Ramli, Y., Pratama, D., Restiawaty, E., Bindar, Y.: Life cycle analysis (LCA) for silica production from three different routes: Conventional, fume, and green routes. In: International Seminar on Chemical Engineering Soehadi Reksowardojo (STKSR) in conjunction with Symphosium on Photocatalyst and Photocatalysis (2020)

18. Atkins, P., de Paula, J.: Physical Chemistry, Ninth Edition. (2010)

19. Spindt, R.S.: Air-Fuel Ratios from Exhaust Gas Analysis. SAE Tech. Pap. Ser. 650507, 788-793 (1965)

20. Parker, S.A., Walker, B.K.: Boilers and Fired Systems. In: Energy Management Handbook, Eighth Edition. pp. 91-129 (2013)

21. Rozainee, M., Ngo, S.P., Salema, A.A., Tan, K.G.: Fluidized bed combustion of rice husk to produce amorphous siliceous ash. Energy Sustain. Dev. 12, 33-42 (2008). https://doi.org/10.1016/S09730826(08)60417-2

22. Rozainee, M., Ngo, S.P., Salema, A.A., Tan, K.G., Ariffin, M., Zainura, Z.N.: Effect of fluidising velocity on the combustion of rice husk in a bench-scale fluidised bed combustor for the production of amorphous rice husk ash. Bioresour. Technol. 99, 703-713 (2008). https://doi.org/10.1016/j.biortech.2007.01.049

23. Mehta, D.P.: Waste Heat Recovery. In: Energy Management Handbook, Eighth Edition. pp. 201-224 (2013) 
24. Wong, J.B., Kovacik, J.M.: Cogeneration and Distributed Generation. In: Energy Management Handbook, Eighth Edition. pp. 161-199 (2013)

25. Ragland, K.W., Bryden, K.M.: Thermodynamics of Combustion. In: Combustion Engineering, Second Edition. pp. 41-90 (2011)

26. Dizaji, H.B., Zeng, T., Hartmann, I., Enke, D., Schliermann, T., Lenz, V., Bidabadi, M.: Generation of high quality biogenic silica by combustion of rice husk and rice straw combined with pre- and posttreatment strategies-A review. Appl. Sci. 9, 1-27 (2019). https://doi.org/10.3390/app9061083

27. Perez-Jimenez, J.A.: Gaseous emissions from the combustion of biomass pellets. WIT Trans. State Art Sci. Eng. 85, 87-99 (2015). https://doi.org/10.2495/978-1-84566-062-8/006

28. Ganesh, A., Grover, P.D., Lyer, P.V.R.: Combustion and gasification characteristics of rice husk. Fuel. 71, 889-894 (1992). https://doi.org/10.1016/0016-2361(92)90238-J

29. Jose, L.S., Bollini, B.L., Silva, M.E. da, Colombaroli, T.S., Tuna, C.E., Araujo, F.H.M. de, Vane, L.F., Pedroso, D.T., Tapia, L.C.F.T., Virgoux, R.Z.: Gibbs free energy as a function of temperature of formation reactions. In: Sustainable Hydrogen Production Processes. p. 183 (2017)

30. Simonov, A.D., Mishenko, T.I.: Combustion and processing of rice husk in the vibrofluidized bed of catalyst or inert material. Chem. Sustain. Dev. 11, 277-283 (2003)

31. Choi, Y., Stenger, H.: Kinetics of methanol decomposition and water gas shift reaction on a commercial Cu-ZnO/Al2O3 catalyst. Fuel Chem. Div. Prepr. 47, 723-724 (2002)

32. Li, Z., Xu, H., Yang, W., Xu, M., Zhao, F.: Numerical investigation and thermodynamic analysis of syngas production through chemical looping gasification using biomass as fuel. Fuel. 246, 466-475 (2019). https://doi.org/10.1016/j.fuel.2019.03.007

33. Rukthong, W., Thanatawee, P., Sunphorka, S., Piumsomboon, P., Chalermsinsuwan, B.: Computation of biomass combustion characteristic and kinetic parameters by using thermogravimetric analysis. Eng. J. 19, 41-57 (2015). https://doi.org/10.4186/ej.2015.19.2.41 
Figures

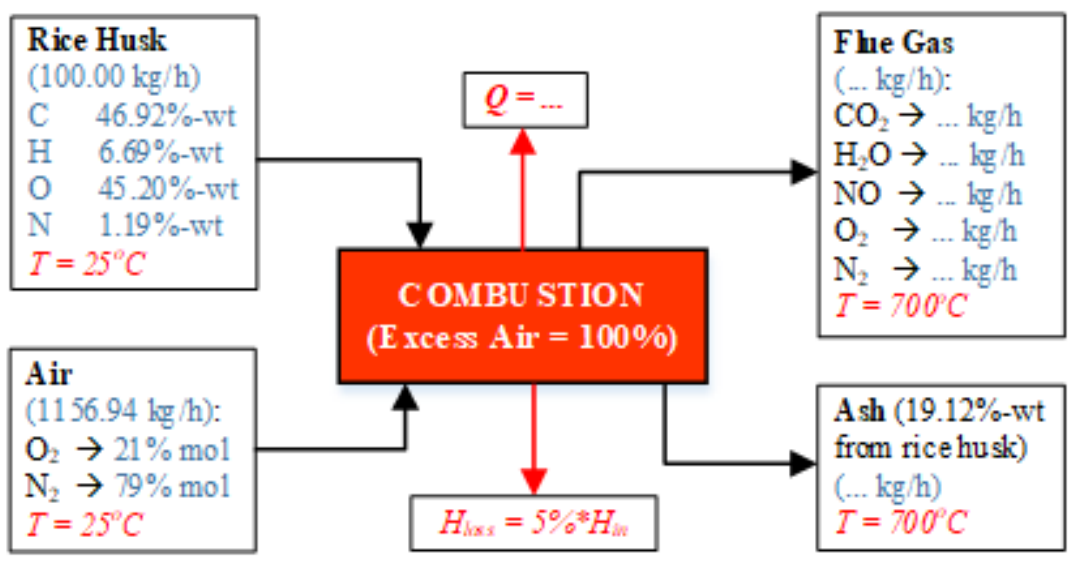

\begin{tabular}{|lcc|}
\hline \multicolumn{3}{|c|}{ Degree of freed om analy sis } \\
Mass balance & Mass-energy balance \\
Mass stream variables & $(12)$ & $(12)$ \\
Energy stream variables & $(0)$ & $(6)$ \\
Linearly independent element balances & $(-5)$ & $(-5)$ \\
Energy equation & $(0)$ & $(-1)$ \\
Known compositions & $(-4)$ & $(-4)$ \\
Known energy variables & $(0)$ & $(-5)$ \\
Basis & $(-1)$ & $(-1)$ \\
Known flowrates & $(-1)$ & $(-1)$ \\
Supplementary equations & $(-1)$ & $(-1)$ \\
\hline Deg ree of freedom & 0 & 0 \\
\hline
\end{tabular}

\section{Figure 1}

Rice husk combustion block diagram with DoF analysis

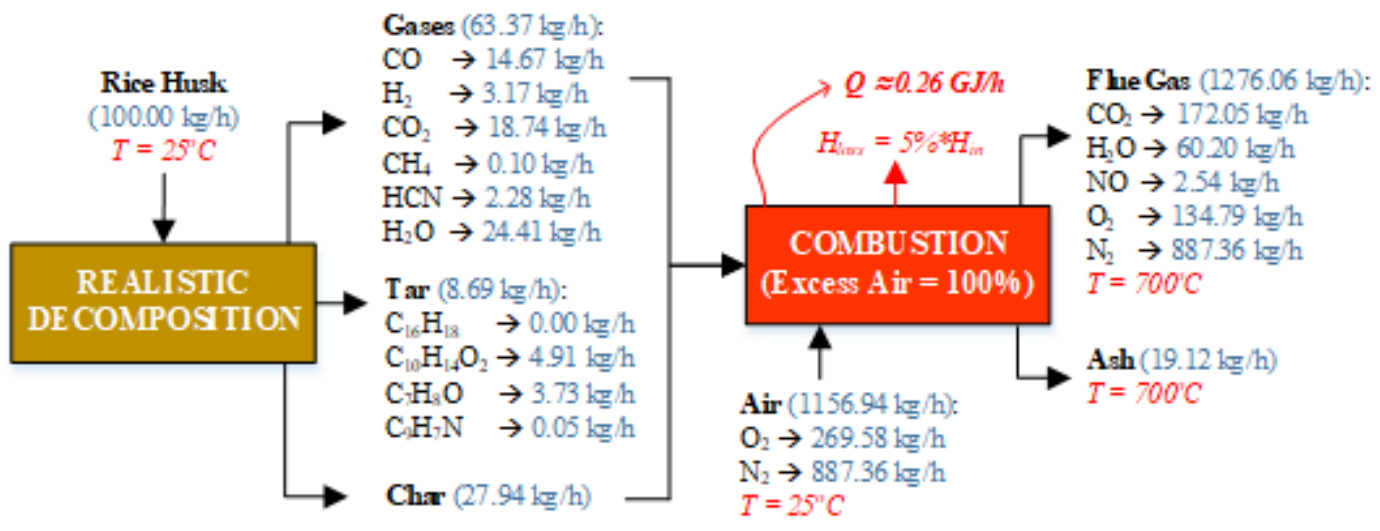

Figure 2

Rice husk combustion calculation based on realistic decomposition 


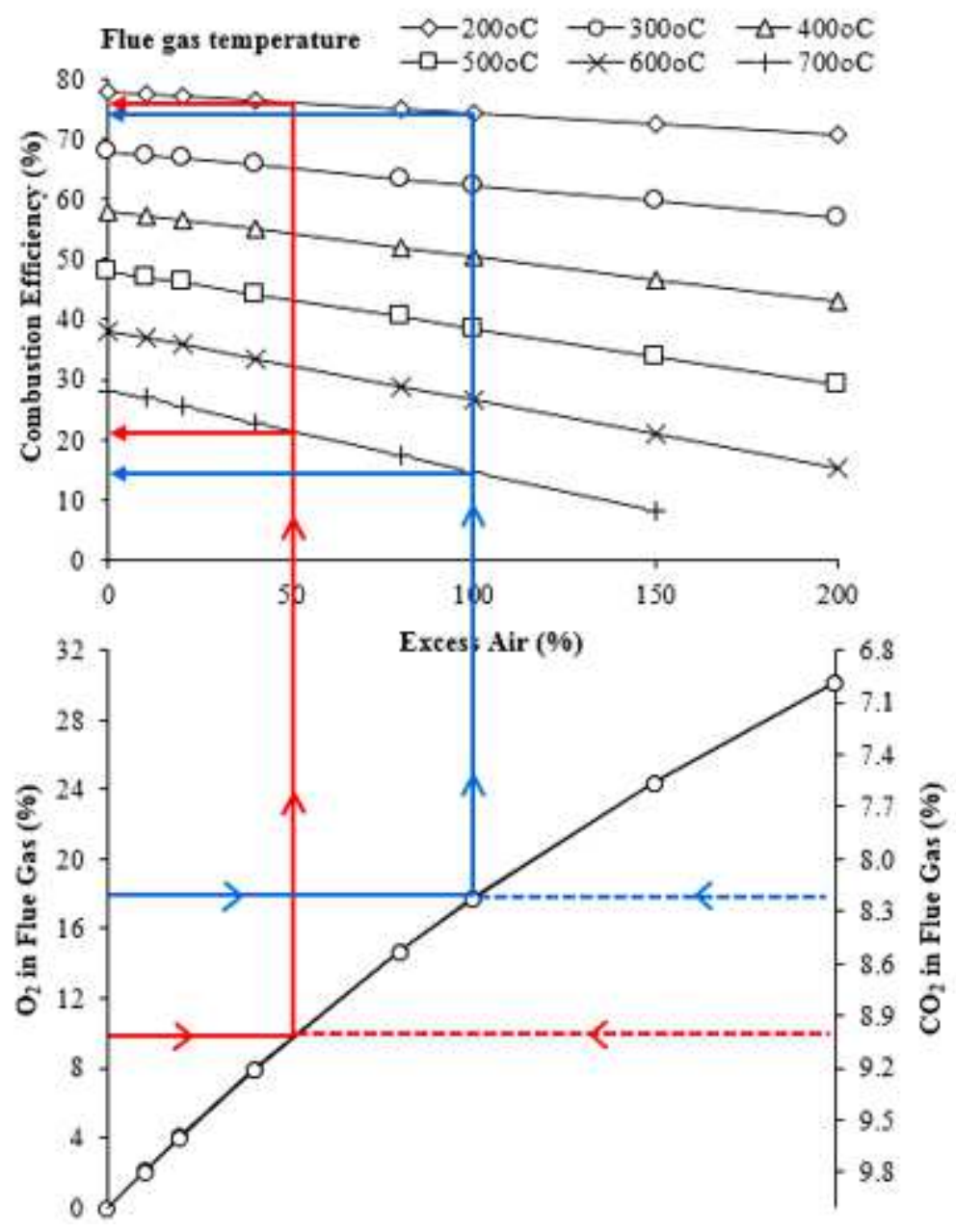

Figure 3

Rice husk combustion efficiency nomogram

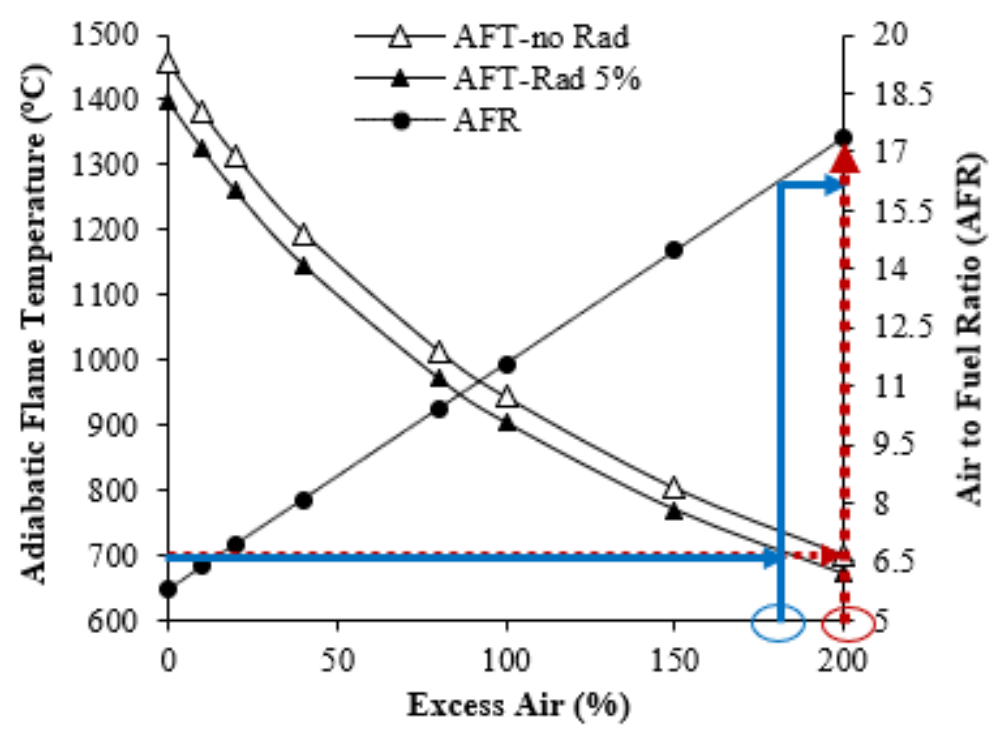

Figure 4

AFT for rice husk combustion at various excess air 


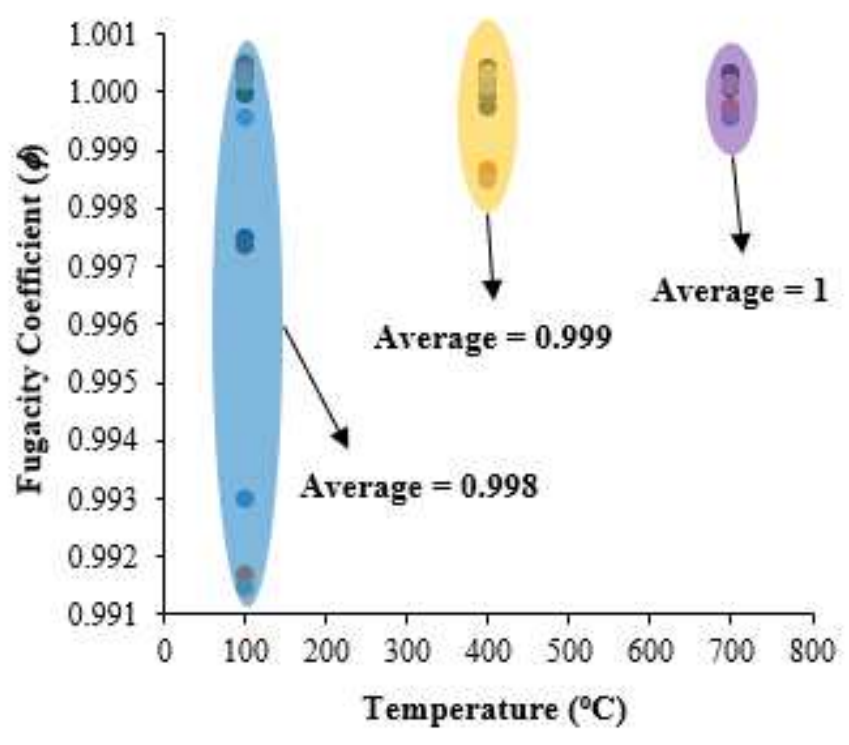

Figure 5

Flue gas fugacity coefficient at various temperature
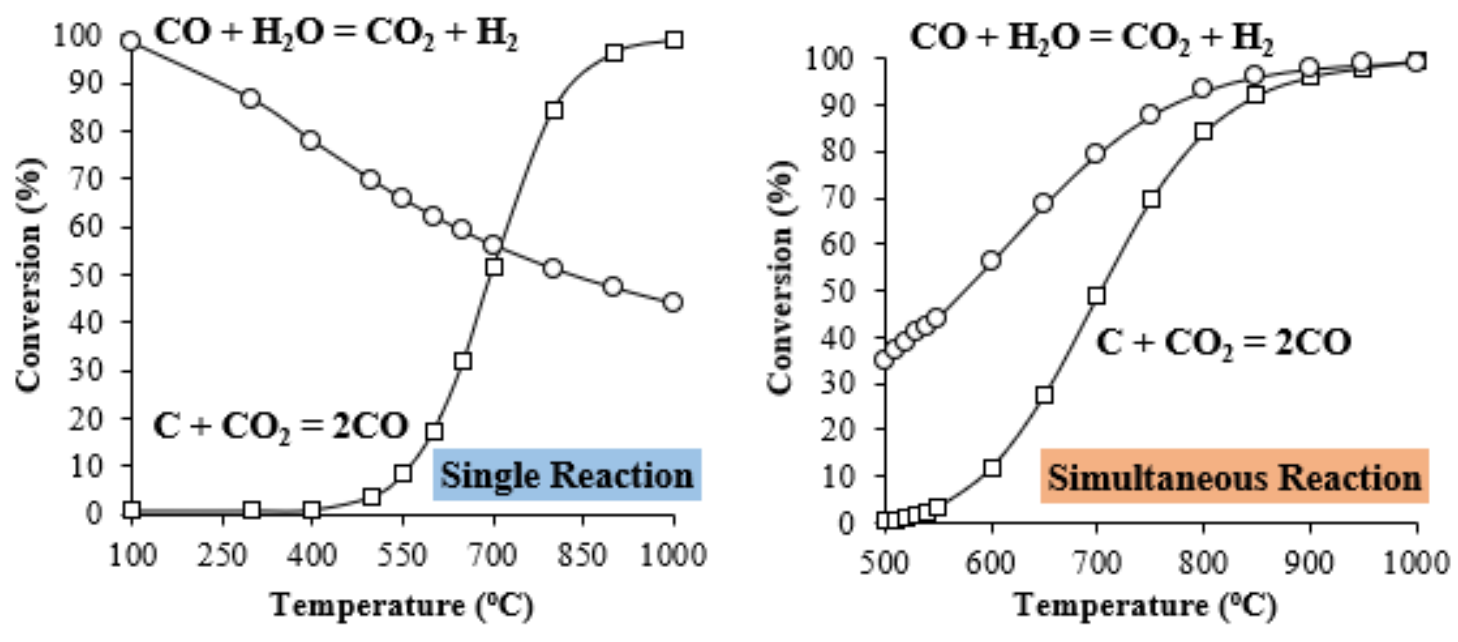

Figure 6

Equilibrium conversion for Boudouard and WGSR: single reaction (a) and simultaneous reaction (b) 


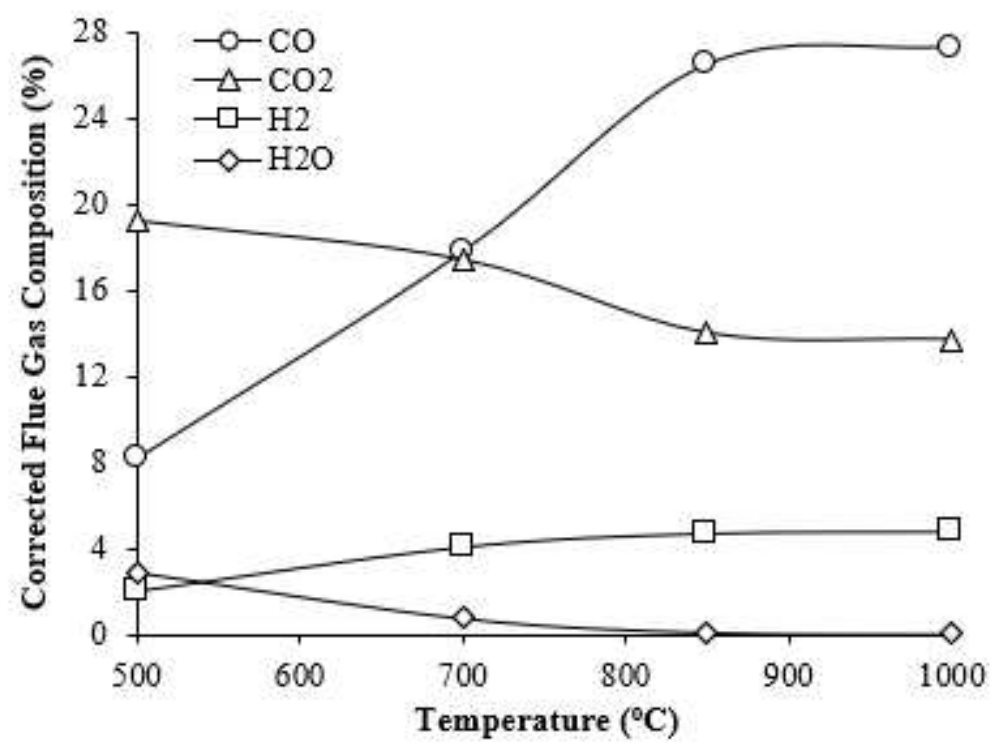

Figure 7

Corrected flue gas composition

\section{Supplementary Files}

This is a list of supplementary files associated with this preprint. Click to download.

- TOCGraphicalabstract.docx 